\title{
Electrophysiological basis of human Fallopian tubal fluid formation
}

\author{
S. J. Downing ${ }^{1}$, S. D. Maguiness ${ }^{2}$, A. Watson ${ }^{2}$ and H. J. Leese ${ }^{1}$ \\ ${ }^{1}$ Department of Biology, University of York, PO Box 373, York YO1 5 YW, UK; and ${ }^{2}$ The Princess \\ Royal Hospital, Saltshouse Road, Hull HU8 9HE, UK
}

\begin{abstract}
A preparation for the maintenance of human Fallopian tubal epithelial cells as a polarized layer in primary culture was used to study the electrophysiological basis of tubal fluid formation in terms of the movement of $\mathrm{Na}^{+}, \mathrm{K}^{+}$and $\mathrm{Cl}^{-}$ions. Transepithelial potential difference $(P D)$ and short-circuit current $\left(I_{\mathrm{scc}}\right)$ were recorded by mounting the epithelial cells in a modified Ussing chamber. Resistance $(R)$ was calculated from the measurements of $P D$ and $I_{\mathrm{scc}}$. The epithelia, although confluent, formed a 'leaky' electrical system and resistances greater than $300 \Omega \mathrm{cm}^{-2}$ were rarely achieved. The sodium channel blocker, amiloride $\left(100 \mu \mathrm{mol} \mathrm{l}^{-1}\right)$, produced only small effects on $P D$ and $I_{\text {scc }}$. The potassium channel blocker, tetraethylammonium chloride (TEA) $\left(25 \mathrm{mmol} \mathrm{l}^{-1}\right)$, also produced small, but significant changes in $P D$, $I_{\text {scc }}$ and $R$ while the chloride channel blocker, 4-acetamido-4'-isothiocyanostilbene-2.2'disulfonic acid (SITS) ( $1 \mathrm{mmol} \mathrm{I}^{-1}$ ), induced a marked increase in $P D$ and $I_{\mathrm{scc}^{\prime}}$ and a fall in $R$, when added to the basal surface of the cells. Bathing the apical surface of the cells with chloride-free medium also produced a marked increase in $P D, I_{\mathrm{scc}}$ and $R$; bathing the basal surface of the cells with chloride-free medium produced a marked decrease in $P D$ and $I_{\text {sce. }}$. Extracellular ATP $\left(10 \mu \mathrm{mol}^{-1}\right)$, added to either the apical or the basal surface of the cells, induced a transient increase in $P D$ and $I_{\mathrm{scc}}$ and a decrease in $R$. Amiloride, TEA or furosemide had no effect on the response of the cells to ATP. SITS, applied to the apical surface, significantly reduced the response of the cells to ATP. We conclude that the major driving force for human tubal fluid formation is the transepithelial secretion of chloride ions into the oviduct lumen and that exogenous ATP is a potential modulator of secretion.
\end{abstract}

\section{Introduction}

The Fallopian tube is the site of ovum and sperm transport, fertilization and early embryo development. Tubal fluid, secreted by the epithelial cells lining the inner surface of the oviduct, provides the optimum environment for these processes, but the mechanism and regulation of its secretion are poorly understood (Leese, 1988). Fluid movements across epithelia are secondary to the movement of solutes, particularly ions. For understanding the basis of human tubal fluid formation, it is necessary to define which ion(s) moves preferentially in a secretory direction, that is from the basal to the apical side of the epithelial cells that border the lumen. Using a vascular perfusion technique, Gott et al. (1988) and Dickens and Leese (1994) found that basal to apical movements of chloride ions were associated with tubal fluid secretion in the rabbit oviduct. These chloride fluxes were sensitive to blockade of $\mathrm{Cl}^{-}-\mathrm{HCO}_{3}{ }^{-}$exchange and $\mathrm{Na}^{+}-\mathrm{K}^{+}-\mathrm{Cl}^{-}$cotransport (Gott et al., 1988) consistent with the oviduct being a $\mathrm{Cl}^{-}$secretory epithelium as is found in other tissues such as the kidney proximal tubule and the airways. Dickens et al. (1993) then devised a method for maintaining rabbit oviduct epithelial cells as a polarized layer in primary culture. In this technique, oviducts were slit open and exposed to an enzyme digest medium and the epithelial cells released

Received 27 February 1997 were grown on collagen-impregnated permeable supports. The significance of this method is that the epithelial cells are maintained in their proper spatial orientation. Their basal surface, which in the intact tissue would be in contact with extracellular fluid, rests on the filter, and their apical surface, which borders the lumen in vivo, is exposed to the upper medium. Since the media on both sides of the cells are accessible, it is possible to mount the preparation in an Ussing chamber and to study transepithelial ionic and electrical events. Use of this preparation showed that chloride ion flux in the secretory (basal to apical) direction was greater than in the absorptive (apical to basal) direction and that transepithelial electrical potential difference $(P D)$ increased in response to adrenergic agonists. Dickens $e t$ al. (1996a) then showed that human tubal epithelial cells could also be grown in a polarized manner.

Extracellular ATP is a potent $\mathrm{Cl}^{-}$secretagogue in airway epithelial cells and has been shown to regulate chloride secretion in a variety of tissues (Chan et al., 1996, 1997; Gorodeski et al., 1996; Hwang et al., 1996; Yamaya et al., 1996). ATP also induces increases in intracellular calcium in epithelia, including airways (Mason et al., 1991; Chan et al., 1996; 1997), and oviduct (Cox and Leese, 1995; Dickens et al., 1996a, 1996b). In cystic fibrosis, epithelial cells characteristically show reduced chloride secretion and thus reduced fluid secretion. The use of ATP and UTP as therapeutic agents in cystic fibrosis has been suggested (Hwang et al., 1996). 
We have now used ion transport inhibitors in our polarized cell preparation to examine the electrophysiological basis of human tubal fluid formation in terms of $\mathrm{Na}^{+}, \mathrm{K}^{+}$and $\mathrm{Cl}^{-}$ion movements and the response to extracellular ATP.

\section{Materials and Methods}

Human Fallopian tubes, at various stages of the menstrual cycle, were removed from pre-menopausal patients attending for hysterectomy at the Princess Royal Hospital, Hull. Permission was granted by the Hull and East Yorkshire Ethics and Clinical Trials Committee and informed consent was obtained.

\section{Epithelial cell culture}

Epithelial cells were isolated according to the method of Dickens et al. (1993) which is a modification of methods devised by Glasser et al. (1988) and Kimber et al. (1993). The tubes were washed in Hank's balanced salt solution without calcium and magnesium ( $\mathrm{Ca}$ - and $\mathrm{Mg}$-free HBSS, Gibco, Life Technologies Ltd, Paisley) and connective tissue was removed. The tubes were opened longitudinally, chopped into $1 \mathrm{~cm}$ pieces and incubated in $\mathrm{Ca}$ - and $\mathrm{Mg}$-free $\mathrm{HBSS}$ containing $0.5 \%(w / v)$ type I trypsin (Sigma Chemical Co., Poole) and $2.7 \%(\mathrm{w} / \mathrm{v})$ pancreatin (Gibco) for $\mathrm{I} h$ at $4^{\circ} \mathrm{C}$, followed by a further incubation for $\mathrm{Ih}$ at room temperature. The enzyme medium was removed, Ca- and Mg-free HBSS added and the epithelial cells vortexed into suspension. After centrifugation at $250 \mathrm{~g}$ for $5 \mathrm{~min}$, the cells were washed three times in Ca- and $\mathrm{Mg}$-free HBSS. After centrifugation, cells were resuspended in prewarmed gassed culture medium at a density of $1 \times 10^{6}$ cells $\mathrm{ml}^{-1}$. Cell viability, tested by the ability to exclude Trypan blue $(0.4 \% \mathrm{w} / \mathrm{v})$, was more than $95 \%$.

For electrophysiological studies, $250 \mu \mathrm{l}$ of the cell suspension was placed in the top of Snapwell filters, $1 \mathrm{~cm}^{2}, 0.4 \mu \mathrm{m}$ pore size (Corning Costar Corporation, Cambridge, MA) coated with Pronectin F (Protein Polymer Technologies, Inc., San Diego) in multiwell plates, and fresh medium was added under the filters. The cells were incubated in a humidified incubator at $37^{\circ} \mathrm{C}$, gassed with $5 \% \mathrm{CO}_{2}$ in air. The medium was replaced above and below the filters every $48 \mathrm{~h}$. When the cells became confluent, the filters were placed in modified Ussing chambers (World Precision Instruments, Inc., Sarasota), with both surfaces of the cells bathed with normal Krebs Ringer solution and gassed with $95 \% \mathrm{O}_{2}: 5 \% \mathrm{CO}_{2}$, at $37.5^{\circ} \mathrm{C}$. Pairs of glass $\mathrm{KCl}$ electrodes were used to clamp the cells electrically alternately at $0 \mathrm{mV}$ for $5 \mathrm{~s}$ and $5 \mu \mathrm{A}$ for $1 \mathrm{~s}$. This procedure permitted almost simultaneous recording of potential difference $(P D)$, and short circuit current $\left(I_{\mathrm{scc}}\right)$. Resistance was calculated from the measurements of $P D$ and $I_{\text {scc }}$. The normal Krebs Ringer bicarbonate solution contained: $118 \mathrm{mmol} \mathrm{NaCl} \mathrm{l}^{-1}$, $25 \mathrm{mmol} \mathrm{NaHCO}_{3} \mathrm{l}^{-\mathrm{I}}, 4.74 \mathrm{mmol} \mathrm{KCl} \mathrm{l} \mathrm{l}^{-1}, 1.19 \mathrm{mmol}$

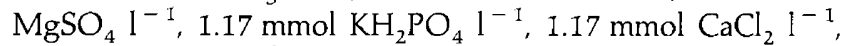
$\mathrm{I}$ mmol glucose $\mathrm{I}^{-1}$ and was gassed with $95 \% \mathrm{O}_{2}: 5 \% \mathrm{CO}_{2}$. In chloride-free medium, $\mathrm{Cl}^{-}$ions were replaced with gluconate. Drugs were made up in normal Krebs Ringer bicarbonate or chloride-free medium and added in volumes of $40 \mu \mathrm{l}$ to either the basal or apical bathing medium and remained in the bathing medium for at least $30 \mathrm{~min}$. The cells were washed and $20 \mathrm{~min}$
Table 1. Response of cultured human Fallopian tube epithelial cells to ATP $\left(10 \mu \mathrm{mol} \mathrm{l}^{-1}\right)$

\begin{tabular}{lcllr}
\hline Treatment & $n$ & \multicolumn{1}{c}{$P D(\mathrm{mV})$} & \multicolumn{1}{c}{$I_{\mathrm{scc}}(\mu \mathrm{A})$} & $R\left(\Omega \mathrm{cm}^{-2}\right)$ \\
\hline Control & 18 & $3.2 \pm 0.3$ & $-11.5 \pm 1.11$ & $96.0 \pm 18.8$ \\
ATP, apical & 18 & $8.6 \pm 1.0^{* * *}$ & $-47.4 \pm 5.8^{* * *}$ & $166.7 \pm 13.0$ \\
Control & 18 & $4.0 \pm 0.4$ & $-14.5 \pm 1.3$ & $207.7 \pm 20.8$ \\
ATP, basal & 18 & $8.6 \pm 1.1^{* * *}$ & $-40.6 \pm 4.7^{* * *}$ & $195.8 \pm 18.8$
\end{tabular}

***P $<0.001$ compared with control value, unpaired Student's \& test.

allowed to elapse before application of the same agonist was repeated to prevent desensitization of the cells to agonists.

Amiloride, tetraethylammonium chloride (TEA), 4-acetamido-4'-isothiocyanostilbene-2.2' -disulfonic acid (SITS), and furosemide were obtained from Sigma Chemical Co. Doses of ion channel blockers used in this study were similar to those used in studies on airway, endometrial, kidney and other cultured epithelia.

Results were analysed statistically by paired or unpaired Student's $t$ tests.

\section{Results}

Epithelial cells from human Fallopian tubes formed a polarized layer, which became confluent usually after 5 to 6 days of culture. Although confluent, the cells formed a rather leaky electrical system; mean values for resting potential difference, short circuit current and resistance were $3.2 \pm 0.2 \mathrm{mV}$, $18.9 \pm 1.0 \mu \mathrm{A}$ and $177.5 \pm 7.0 \Omega \mathrm{cm}^{-2}$, respectively $(n=68$ filters). The filters were used only if values for resistance of at least approximately $100 \Omega \mathrm{cm}^{-2}$ could be achieved. The cells responded to ATP $\left(10 \mu \mathrm{mol}^{-1}\right)$ applied either to the apical or the basal surface; there was a marked transient increase in $P D$ and $I_{\mathrm{scc}}$ and a small decrease in resistance (Table 1 ). The peak response to ATP applied to the apical surface was $P D: 168 \%$ increase $(P<0.001), I_{\text {scc }}: 312 \%$ increase, $(P<0.001)$ and $R$ : $14.9 \%$ decrease. When ATP was applied to the basal surface the peak response was $P D: 115 \%$ increase $(P<0.001), I_{\text {scc: }}$ : $180 \%$ increase $(P<0.001)$ and $R: 5.7 \%$ decrease. No effect of the stage of the menstrual cycle on resting $P D$ and $I_{\mathrm{scc}}$ or on response to agonists was observed.

\section{Effect of ion channel blockers on $\mathrm{PD}, \mathrm{I}_{\text {scc }}$ and resistance}

The sodium channel blocker, amiloride $\left(10 \mu \mathrm{mol} \mathrm{l^{-1 }}\right)$, applied to the basal surface of the epithelial cell layer, produced a significant increase in $P D$ only $(P<0.02)$ (Table 2 ). When applied to the apical surface, a significant decrease in $I_{\text {scc }}$ was observed $(P<0.001)$.

The potassium channel blocker, TEA $\left(25 \mathrm{mmol} \mathrm{l}^{-1}\right)$ applied to the apical surface of the cells, induced a small but significant decline in PD $(P<0.001)$ and $I_{\text {scc }}(P<0.001)$ and a significant increase in $R(P<0.05)$ (Table 2$)$. When applied to the basal cell surface, TEA induced an increase in $P D(P<0.001)$ and $I_{\text {scc }}$ $(P<0.001)$ with a small reduction in $R(P<0.05)$.

The chloride channel blocker, SITS $\left(1 \mathrm{mmol} \mathrm{l}^{-1}\right)$ added to the apical surface of the cell layer had little effect on $P D, I_{\text {scc }}$ or 
Table 2. Effect of amiloride $\left(10 \mu \mathrm{mol} \mathrm{l} \mathrm{l}^{-1}\right)$ or tetraethylammonium chloride (TEA) $\left(25 \mathrm{mmol} \mathrm{l} \mathrm{l}^{-1}\right)$ on electrophysiological properties of cultured human Fallopian tube epithelial cells

\begin{tabular}{lrlll}
\hline Treatment & $n$ & $P D(\mathrm{mV})$ & $I_{\mathrm{scc}}(\mu \mathrm{A})$ & $R\left(\Omega \mathrm{cm}^{-2}\right)$ \\
\hline Control & 9 & $4.8 \pm 0.7$ & $-18.0 \pm 2.1$ & $211.1 \pm 28.0$ \\
Amiloride, apical & 9 & $4.4 \pm 0.8$ & $-12.8 \pm 1.8^{* * *}$ & $250.1 \pm 32.0$ \\
Control & 5 & $4.5 \pm 0.8$ & $-14.8 \pm 2.6$ & $217.4 \pm 18.7$ \\
Amiloride, basal & 5 & $6.2 \pm 1.1^{* *}$ & $-17.8 \pm 2.8$ & $264.7 \pm 14.2$ \\
Control & 12 & $6.0 \pm 0.4$ & $-35.5 \pm 3.3$ & $152.4 \pm 11.6$ \\
TEA, apical & 12 & $4.8 \pm 0.5^{* * *}$ & $-25.5 \pm 2.9^{* * *}$ & $169.0 \pm 14.3^{*}$ \\
Control & 12 & $4.9 \pm 0.5$ & $-25.2 \pm 2.9$ & $166.6 \pm 11.5$ \\
TEA, basal & 12 & $6.1 \pm 0.5^{* * *}$ & $-35.8 \pm 3.9^{* * *}$ & $158.5 \pm 12.5^{*}$ \\
\hline
\end{tabular}

${ }^{*} P<0.05, * * P<0.02, * * * P<0.001$, compared with control value, paired Student's $t$ test.

(a)

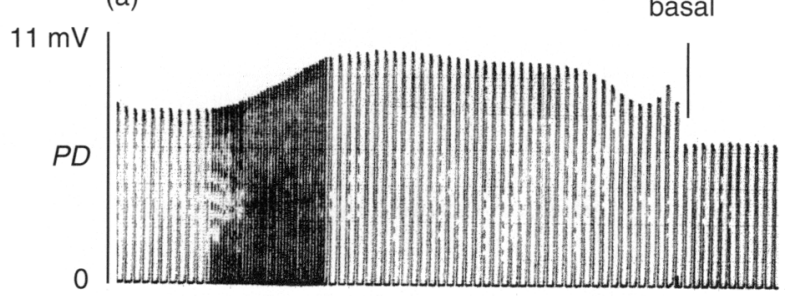

(b)

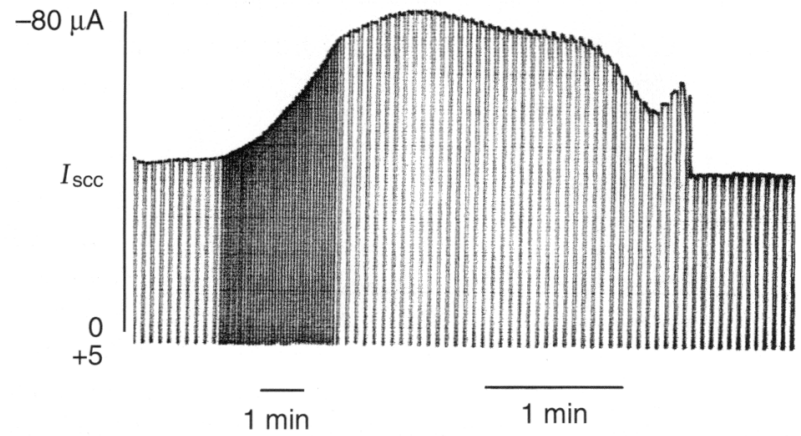

Fig. 1. Recordings of transepithelial potential difference (a) and short-circuit current (b) in cultured epithelial cells from human Fallopian tubes, during alternating voltage clamp at $0 \mathrm{mV}$ for $5 \mathrm{~s}$ and current clamp at $5 \mu \mathrm{A}$ for $1 \mathrm{~s}$. Effect of $1 \mathrm{mmol} 4$-acetamido-4'isothiocyanostilbene-2.2'-disulfonic acid (SITS) $1^{-1}$ applied to the basal surface of the cells.

$R$. When applied to the basal surface, SITS induced a multiphasic response consisting of an acute increase in $P D(P<0.01)$ and $I_{\text {scc }}(P<0.01)$, and a decrease in $R(P<0.01)$, followed by a slight decrease in $P D$ and $I_{\text {scc }}$ which was then followed by a more sustained increase in both $P D$ and $I_{\text {scc }}$. After approximately $30 \mathrm{~min}, P D$ was still significantly raised $(P<0.02)$ but $I_{\text {scc }}$ had declined to pre-SITS values (Fig. I, Table 3).

Furosemide (100 $\mu \mathrm{mol} \mathrm{l}^{-1}$ ) had little effect when applied to the apical surface of the cells other than producing a small increase in $R$. Unlike SITS, furosemide did not elicit a biphasic response when applied to the basal surface of the cells, such that by $20-30 \mathrm{~min}, P D$ was unchanged; however, $I_{\text {scc }}$ was significantly reduced $(P<0.05)$ and $R$ was significantly increased $(P<0.01$ ) (Table 3 ).
Furosemide $\left(100 \mu \mathrm{mol} \mathrm{l}^{-1}\right)$ and SITS $\left(1 \mathrm{mmol} \mathrm{l}^{-1}\right)$ applied together to the apical surface of the cells had little effect other than a small, but significant increase in $R(P<0.05)$. Furosemide and SITS applied to the basal surface of the cells induced a transient increase in PD and $I_{\text {scc }}$ as with SITS alone. By 20-30 min, $P D$ and $I_{\text {scc }}$ values were similar to pretreatment values, although there appeared to be a small but significant increase in $R(P<0.05)$.

\section{Effect of chloride-free medium}

Replacing the medium bathing the apical surface of the cells with chloride-free medium resulted in an immediate fourfold increase in $P D(P<0.01)$ and a sixfold increase in $I_{\text {scc }}(P<0.01)$. Resistance was not significantly changed (Table 4, Fig. 2). By 20-30 min after application of chloride-free medium, $P D$ had declined but was still three times higher than pretreatment values $(P<0.01)$. $I_{\text {scc }}$ declined more rapidly although it remained 2.5 times higher than pretreatment values $(P<0.05)$. As a result, however, resistance increased significantly $(P<0.002)$ (Table 4$)$.

Replacing the medium bathing the basal surface of the cells with chloride-free medium for 20 min produced a marked fall in $P D$ to a negative value (Table $4, P<0.001$, Fig. 3 ) and the electrical polarity of $I_{\text {scc }}$ also reversed $(P<0.02)$. When both surfaces of the cells were exposed to chloride-free medium, an increase in $P D$ (Table $4, P<0.02$ ), and a marked increase in resistance $(P<0.01)$ were observed.

Effect of ion channel blockers and chloride-free medium on epithelial cell response to ATP

Amiloride, TEA or furosemide had no significant effect on the response of the epithelial cells to ATP $\left(10 \mu \mathrm{mol} \mathrm{l}{ }^{-1}\right)$, applied to either apical or basal surface. SITS, applied to the basal surface of the epithelial cells did not affect the response to ATP applied to the basal surface; however, when applied to the apical surface of the cells SITS significantly reduced the rise in $P D$ and $I_{\text {scc }}(P<0.05)$ and the decrease in $R(P<0.01)$ normally observed in response to ATP applied apically (Table 5). Similarly, furosemide and SITS, applied together to the basal surface did not affect the response of the cells to ATP, but furosemide and SITS applied to the apical surface significantly 
Table 3. Effect of 4-acetamido-4'-isothiocyanostilbene-2.2'-disulfonic acid (SITS) ( $1 \mathrm{mmol} 1^{-1}$ ), furosemide $\left(100 \mu \mathrm{mol} \mathrm{l}^{-1}\right)$ or both drugs on electrophysiological properties of cultured human Fallopian tube epithelial cells

\begin{tabular}{lllll}
\hline Treatment & $n$ & $P D(\mathrm{mV})$ & $I_{\mathrm{scc}}(\mu \mathrm{A})$ & $R\left(\Omega \mathrm{cm}^{-2}\right)$ \\
\hline Control & 6 & $4.4 \pm 1.2$ & $-24.0 \pm 6.6$ & $143.0 \pm 12.8$ \\
SITS, basal, immediate & 6 & $7.4 \pm 1.9^{* * *}$ & $-51.8 \pm 12.9^{* *}$ & $108.3 \pm 22.3^{* * *}$ \\
Control & 6 & $4.2 \pm 0.9$ & $-18.7 \pm 2.9$ & $176.6 \pm 33.8$ \\
SITS, basal, 20 min & 6 & $5.0 \pm 1.0^{* *}$ & $-19.2 \pm 2.5$ & $219.9 \pm 52.1$ \\
Control & 10 & $4.5 \pm 0.6$ & $-22.8 \pm 3.1$ & $165.1 \pm 21.5$ \\
SITS, apical & 10 & $4.2 \pm 0.6$ & $-20.4 \pm 2.5$ & $173.8 \pm 23.4$ \\
Control & 10 & $4.9 \pm 0.4$ & $-19.0 \pm 1.8$ & $211.6 \pm 19.1$ \\
Furosemide, apical & 10 & $5.2 \pm 0.4$ & $-17.2 \pm 2.4$ & $243.9 \pm 19.8^{* *}$ \\
Control & 7 & $4.3 \pm 0.4$ & $-18.3 \pm 2.2$ & $195.2 \pm 20.8$ \\
Furosemide, basal & 7 & $4.7 \pm 0.5$ & $-14.4 \pm 2.4^{*}$ & $246.3 \pm 23.1^{* * *}$ \\
Control & 8 & $3.8 \pm 0.5$ & $-17.0 \pm 1.8$ & $167.1 \pm 18.1$ \\
Furosemide + SITS, apical & 8 & $3.8 \pm 0.6$ & $-14.8 \pm 2.5$ & $197.9 \pm 27.7^{*}$ \\
Control & 7 & $3.2 \pm 0.7$ & $-13.0 \pm 2.2$ & $170.6 \pm 22.1$ \\
Furosemide + SITS, basal & 7 & $3.4 \pm 0.6$ & $-11.6 \pm 1.7$ & $204.9 \pm 31.0^{*}$ \\
\hline
\end{tabular}

${ }^{*} p<0.05,{ }^{* *} P<0.02,{ }^{* * *} P<0.01$ compared with control value, paired Student's $t$ test.

Table 4. Effect of chloride-free medium on electrophysiological properties of cultured human Fallopian tube epithelial cells

\begin{tabular}{lcccl}
\hline Treatment & $n$ & $P D(\mathrm{mV})$ & $I_{\mathrm{scc}} \mathrm{S}(\mu \mathrm{A})$ & $R\left(\Omega \mathrm{cm}^{-2}\right)$ \\
\hline Control & 6 & $3.6 \pm 0.7$ & $-13.8 \pm 2.9$ & $186.4 \pm 22.3$ \\
$\mathrm{Cl}^{-}$free, apical, immediate & 6 & $15.5 \pm 2.0^{* * *}$ & $-88.2 \pm 13.9^{* * *}$ & $171.6 \pm 13.8$ \\
$\mathrm{Cl}^{-}$free & 6 & $11.1 \pm 1.3^{* * *}$ & $-36.7 \pm 6.3^{*}$ & $279.5 \pm 30.2^{+}$ \\
$\mathrm{Control}$ & 6 & $4.9 \pm 0.4$ & $-25.0 \pm 3.2$ & $170.0 \pm 20.3$ \\
$\mathrm{Cl}^{-}$free, basal & 6 & $-1.4 \pm 1.0^{\dagger+}$ & $+15.2 \pm 5.7^{* *}$ & $159.6 \pm 29.8$ \\
$\mathrm{Control}^{-}$ & 4 & $3.5 \pm 0.5$ & $-16.5 \pm 2.6$ & $162.3 \pm 8.4$ \\
$\mathrm{Cl}^{-}$free, both sides & 4 & $6.5 \pm 0.5^{* *}$ & $-12.3 \pm 0.5$ & $374.8 \pm 28.7^{* * *}$ \\
\hline
\end{tabular}

${ }^{*} P<0.05,{ }^{* *} P<0.02,{ }^{* * *} P<0.01,{ }^{\dagger} P<0.002,{ }^{\dagger \dagger} P<0.001$, compared with control value, paired Student's $t$ test.

reduced the response of the epithelial cells to ATP applied to the apical surface (Table 5). Chloride-free medium applied to either the apical or basal surface of the cells did not affect the response to ATP; however, bathing both surfaces of the cells with chloride-free medium significantly reduced the increase in $P D$ in response to ATP applied to the apical surface of the cells.

\section{Discussion}

Previous studies using this culture method for human oviducts have demonstrated that a pure population of epithelial cells is obtained and that the cells form a polarized layer (Dickens et al., 1995; Dickens et al., 1996a). The oviduct epithelium is considered to be electrically 'leaky' (Leese, 1988), with high bidirectional fluxes of ions occurring, probably via paracellular junctions, and resistances above $300 \Omega \mathrm{cm}^{-2}$ were rarely achieved. The role of ion fluxes in establishing the transepithelial $P D$ and short circuit current was investigated using ion channel blockers. Amiloride, which inhibits $\mathrm{Na}^{+}-\mathrm{H}^{+}$ exchange, had a relatively small effect on $P D$ and $I_{\text {scc }}$ of the tubal epithelial cells, with maximum effects of the order of a $10-15 \%$ change in $P D$ only. This finding suggests that $\mathrm{Na}^{+}-\mathrm{H}^{+}$exchange does not greatly influence transepithelial PD. TEA, a relatively non-specific blocker of $\mathrm{K}^{+}$channels, showed greater, more consistent effects on the electrical properties of the cells. When applied to the apical surface, $P D$ declined by $20 \%$ and $I_{\text {scc }}$ by $30 \%$; when applied to the basal surface, $P D$ increased steadily by $30 \%$ and $I_{\text {scc }}$ by $50 \%$ over $30 \mathrm{~min}$. Movement of $\mathrm{K}^{+}$ions may, therefore, play a role in controlling transepithelial PD. SITS, a blocker of $\mathrm{Cl}^{-}-\mathrm{HCO}_{3}{ }^{-}$ exchange, had a marked initial effect when applied to the basal surface with the cells returning to equilibrium over $20-30 \mathrm{~min}$. The effect of SITS was small when applied to the apical surface. Similarly, the influence of furosemide, a blocker of the $\mathrm{Na}^{+}-\mathrm{K}^{+}-\mathrm{Cl}^{-}$transporter, was small at the apical surface of the cells. Unlike SITS, furosemide applied basally did not produce the marked, transient increase in $P D$ and $I_{\text {scc. }}$ After $30 \mathrm{~min}$, however, furosemide had produced a significant increase in resistance, suggesting that movement of ions via the $\mathrm{Na}^{+}-\mathrm{K}^{+}-\mathrm{Cl}^{-}$cotransporter was inhibited, particularly at the basal membrane. The effects of SITS and furosemide applied together were similar to those of SITS alone, at both the apical and basal surfaces, suggesting that there were no additive or 


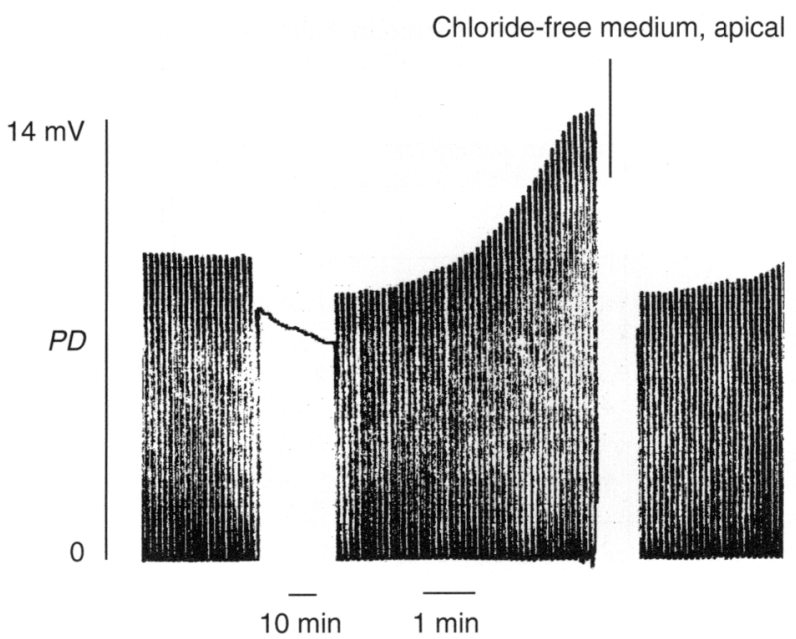

Fig. 2. Recording of transepithelial potential difference in cultured epithelial cells from human Fallopian tubes, during alternating voltage clamp at $0 \mathrm{mV}$ for $5 \mathrm{~s}$ and current clamp at $5 \mu \mathrm{A}$ for $1 \mathrm{~s}$. Effect of bathing the apical surface of the cells in chloride-free medium.

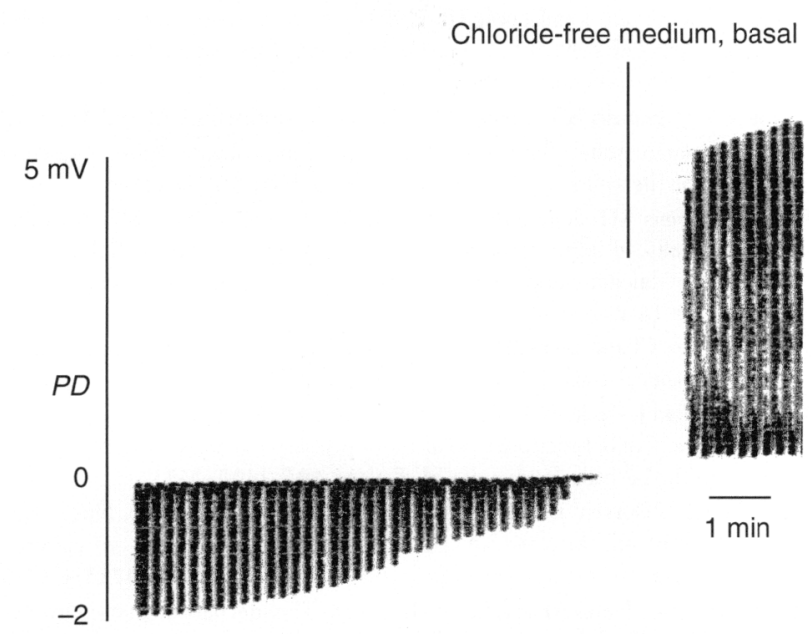

Fig. 3. Recording of transepithelial potential difference in cultured epithelial cells from human Fallopian tubes, during alternating voltage clamp at $0 \mathrm{mV}$ for $5 \mathrm{~s}$ and current clamp at $5 \mu \mathrm{A}$ for $1 \mathrm{~s}$. Effect of bathing the basal surface of the cells in chloride-free medium.

synergistic effects of the two $\mathrm{Cl}^{-}$channel blockers. This finding suggests that $\mathrm{Cl}^{-}-\mathrm{HCO}_{3}{ }^{-}$exchange plays an important role in determining transepithelial $P D$ and that this activity occurs predominantly at the basal membrane.

In secretory epithelia, chloride ion movements from the basal to apical poles of the cells play a significant role in providing the driving force for fluid movement (O'Grady et al., 1987; Case ef al., 1989; Quinton, 1990). A low intracellular $\mathrm{Na}^{+}$concentration is maintained by the $\mathrm{Na}^{+}-\mathrm{K}^{+}$-ATPase, with uptake of $\mathrm{Cl}^{-}$via $\mathrm{Na}^{+}-\mathrm{K}^{+}-\mathrm{Cl}^{-}$cotransporter occurring at the basolateral membrane. The apical membrane also becomes permeable to $\mathrm{Cl}^{-}$, which allows the anion to move down an electrochemical gradient. The $\mathrm{Cl}^{-}$ion movements generate an electrical force which drives $\mathrm{Na}^{+}$paracellularly through the tight junctions between cells into the lumen, creating a higher luminal osmotic pressure. Water follows the ion movements towards the osmotic equilibrium and thus accumulates in the lumen (Quinton, 1990). Movements of chloride ions from basal to apical have been observed in the epithelium of the Fallopian tube consistent with it being a chloride secretory epithelium (Brunton and Brinster, 1971; Gott et al., 1988; Dickens et al., 1993, 1995) and our present data are in agreement with this. In vascularly perfused rabbit oviduct, inhibition of chloride ion transport decreased vascular to lumen $\mathrm{Cl}^{-}$flux and reduced the rate of fluid secretion (Dickens and Leese, 1994).

The lack of effect of amiloride, in contrast to that observed in cultured human endometrial epithelium (Matthews et al., 1993), suggests that $\mathrm{Na}^{+}$ion movements do not contribute substantially to the transepithelial potential difference in tubal epithelia. By contrast, the changes in transepithelial $P D$ observed after TEA treatment suggest that $\mathrm{K}^{+}$movements play a significant role in generating the $P D$. TEA is a relatively non-specific blocker of $\mathrm{K}^{+}$channels; however, since furosemide had less effect on PD than did TEA, this would suggest that $\mathrm{K}^{+}$exerts its influence on transepithelial $P D$ via channels other than the $\mathrm{Na}^{+}-\mathrm{K}^{+}-\mathrm{Cl}^{-}$cotransporter. In this context, it is significant that James and Okada (1994) reported the presence of a $\mathrm{Ca}^{2+}$-activated $\mathrm{K}^{+}$channel in the apical membrane of rabbit oviduct epithelial cells. It is likely that basal to apical movements of $\mathrm{K}^{+}$are important, since the concentration of this ion in oviduct fluid in a number of species is about three times that of plasma (Leese, 1988; Dickens and Leese, 1994). SITS appeared to have a marked, transient effect on transepithelial PD at the basal surface of the cells, suggesting, in human Fallopian tubal cells, that $\mathrm{Cl}^{-}-\mathrm{HCO}_{3}{ }^{-}$ exchange is an important short-term mediator of $\mathrm{Cl}^{-}$movements. That the effect of SITS was transient suggests that alternative mechanisms of chloride uptake at the basal membrane can come into operation. Furosemide had no additive effects with SITS, nor did it prolong the effectiveness of SITS, suggesting that the control of ion movements via the $\mathrm{Na}^{+}-$ $\mathrm{K}^{+}-\mathrm{Cl}^{-}$co-transporter occurs later than via $\mathrm{Cl}^{-}-\mathrm{HCO}_{3}{ }^{-}$ exchange. The effects of chloride-free medium were more lasting; bathing the apical surface of the cells with chloride-free medium resulted in a fourfold increase in $P D$, presumably resulting from the increase in movement of $\mathrm{Cl}^{-}$down the electrochemical gradient towards the apical surface; bathing the basal surface of the epithelial cells with chloride-free medium resulted in a marked reduction in transepithelial $P D$, such that a reversal of electrical polarity occurred. This finding suggests that the flux of $\mathrm{Cl}^{-}$ions, in response to the reversed electrochemical gradient, becomes apical to basal, which would be characteristic of an absorptive epithelium or a volumesensitive, osmoregulatory epithelium. These observations support the proposition that $\mathrm{Cl}^{-}$movements, basal to apical, are a major factor determining transepithelial $P D$ in normal Fallopian tube epithelial cells.

ATP induced a transient increase in $P D$ and $I_{\mathrm{scc}}$ as observed previously, in bovine (Cox and Leese, 1995) and human (Dickens et al., 1996a) cultured oviduct cells. In the present study, we observed that the apical surface of the cells may be a little more sensitive to ATP than is the basal surface, as was found in endometrial epithelial cells (Chan et al., 1997). ATP has been shown to influence the secretory activity of epithelial cells in a number of tissues (Mason et al., 1991; Chan et al., 
Table 5. Effect of ion channel blockers or chloride-free medium on response of human Fallopian tube epithelial cells to ATP $\left(10 \mu \mathrm{mol} \mathrm{l}^{-1}\right)$

\begin{tabular}{lrccc}
\hline & \multicolumn{4}{c}{ Percentage change in parameter } \\
\cline { 2 - 5 } Treatment & $n$ & $P D(\mathrm{mV})$ & $I_{\mathrm{scc}}(\mu \mathrm{A})$ & $R\left(\Omega \mathrm{cm}^{-2}\right)$ \\
\hline ATP, apical & 10 & $+151.1 \pm 34.9$ & $+301.9 \pm 78.4$ & $-16.4 \pm 2.6$ \\
SITS, apical, ATP, apical & 10 & $+64.4 \pm 19.3^{*}$ & $+103.4 \pm 32.2^{*}$ & $-6.7 \pm 1.6^{* * *}$ \\
ATP, apical & 8 & $+139.7 \pm 29.1$ & $+299.1 \pm 69.2$ & $-14.4 \pm 3.1$ \\
SITS + furosemide, apical, ATP apical & 8 & $+47.4 \pm 14.8^{* *}$ & $+87.7 \pm 28.7^{* *}$ & $-8.4 \pm 2.0$ \\
ATP, apical & 4 & $+93.9 \pm 16.7$ & $+161.3 \pm 27.1$ & $-12.2 \pm 7.0$ \\
Cl $^{-}$-free both sides, ATP apical & 4 & $+43.1 \pm 8.2^{*}$ & $+91.9 \pm 19.7$ & $-9.4 \pm 1.7$ \\
\hline
\end{tabular}

${ }^{*} P<0.05,{ }^{* * P}<0.02,{ }^{* * *} P<0.01$ compared with ATP response in the absence of ion channel blocker, unpaired Student's $t$ test. SITS: 4-acetamido-4'-isothiocyanostilbene- $2.2^{\prime}$-disulfonic acid.

1996; Gorodeski et al., 1996; Hwang et al., 1996; Yamaya et al., 1996) acting via purinergic receptors. ATP was effective in the present system whether applied basally or apically. Neither amiloride nor TEA affected the response of the epithelial cells to ATP, suggesting that $\mathrm{Na}^{+}$and $\mathrm{K}^{+}$are not involved in this response, as was observed in endometrial epithelial cells (Chan et al., 1997). SITS, with or without furosemide applied to the apical surface of the cells, reduced the response of the cells to apical ATP by a small, but significant amount. This finding suggests that $\mathrm{Cl}^{-}$movement may be important in the effect of ATP on transepithelial PD. In other tissues, extracellular ATP has been shown to induce chloride secretion (Hwang et al., 1996; Yamaya et al., 1996). The enhanced chloride secretion has been shown to depend on an increase in intracellular $\mathrm{Ca}^{2+}$ concentration, either by release from intracellular stores or influx of extracellular $\mathrm{Ca}^{2+}$ (Mason et al., 1991; Chan et al., 1996, 1997; Yamaya et al., 1996). A significant increase in intracellular $\mathrm{Ca}^{2+}$ has also been observed in response to ATP in cultured rabbit, bovine and human oviduct cells (Cox and Leese, 1995; Dickens et al., 1996a,b). We have previously suggested that exogenous ATP, perhaps derived from the oviduct epithelium or from spermatozoa, promotes the secretion of glycoproteins and the activity of cilia (Dickens et al., 1996a,b) and in this way regulates the environment for fertilization and early embryo development.

This work was supported by the Medical Research Council and The Wellcome Trust. The authors thank J. Matthews, Department of Physiology, University of Newcastle-upon-Tyne for valuable advice on the Ussing technique.

\section{References}

Brunton WJ and Brinster RL (1971) Active chloride transport in the isolated rabbit oviduct American Journal of Physiology 221 658-661

Case RM, Lau KR, Steward M, Brown PD and Elliott AC (1989) Molecular mechanisms of transport: small and large molecules Biochemical Society Transactions 17 803-805

Chan HC, Cheung WT, Leung PY, Wu LJ, Cheng Chew SB, Ko WH and Wong PYD (1996) Purinergic regulation of anion secretion by cystic fibrosis pancreatic duct cells American Journal of Physiology 271 C469-C477

Chan HC, Liu CQ, Fong SK, Law SH, Wu LJ, So E, Chung YW, Ko WH and Wong PYD (1997) Regulation of $\mathrm{Cl}^{-}$secretion by extracellular ATP in cultured mouse endometrial epithelium Journal of Membrane Biology 156 45-52
Cox CI and Leese HJ (1995) Effect of purinergic stimulation on intracellular calcium concentration and transepithelial potential difference in cultured bovine oviduct cells Biology of Reproduction 52 1244-1249

Dickens $\mathrm{CJ}$ and Leese $\mathrm{HJ}$ (1994) The regulation of rabbit oviduct fluid formation Journal of Reproduction and Fertility 100 577-581

Dickens CJ, Southgate J and Leese HJ (1993) Use of primary cultures of rabbit oviduct epithelial cells to study the ionic basis of tubal fluid formation Journal of Reproduction and Fertility 98 603-610

Dickens CJ, Maguiness SD, Comer MT, Palmer A, Rutherford AJ and Leese HJ (1995) Human tubal fluid formation and composition during vascular perfusion of the Fallopian tube Human Reproduction 10 505-508

Dickens Cl, Comer MT, Southgate J and Leese HJ (1996a) Human Fallopian tubal epithelial cells in vitro: establishment of polarity and potential role of intracellular calcium and extracellular ATP in fluid secretion Human Reproduction 11 212-217

Dickens CJ, Cox CI and Leese HJ (1996b) Intracellular calcium in cultured rabbit oviduct epithelial cells Reproduction Fertility and Development 8 243-247

Glasser SR, Julian J, Decker GL, Tang J-P and Carson DD (1988) Development of morphological and functional polarity in primary cultures of immature rat uterine epithelial cells Journal of Cell Biology 107 2409-2423

Gorodeski GI, Petersen DE, De Santis BJ and Hopfer U (1996) Nucleotide receptor-mediated decrease of tight-junctional permeability in cultured human cervical epithelium American Journal of Physiology 270 C1715-C1725

Gott AL, Gray SM, James AF and Leese HJ (1988) The mechanism and control of rabbit oviduct fluid formation Biology of Reproduction 39 758-763

Hwang T-H, Schwiebert EM and Guggino WB (1996) Apical and basolateral ATP stimulates tracheal epithelial chloride secretion via multiple purinergic receptors American Journal of Physiology 270 C1611-C1623

James AF and Okada Y (1994) Maxi-K ${ }^{+}$channels from the apical membranes of rabbit oviduct epithelial cells Journal of Membrane Biology 137 109-118

Kimber SJ, Waterhouse $\mathbf{R}$ and Lindenberg S (1993) In vitro models for implantation in the mammalian embryo. In Preimplantation Embryo Development, Serono Symposia USA pp 244-263 Ed. BD Bavister. Springer-Verlag, New York

Leese HJ (1988) The formation and function of oviduct fluid Journal of Reproduction and Fertility $82843-856$

Mason SJ, Paradiso AM and Boucher RC (1991) Regulation of transepithelial ion transport and intracellular calcium by extracellular ATP in human normal and cystic fibrosis airway epithelium British Joumal of Pharmacology 103 1649-1656

Matthews CJ, Thomas EJ, Redfern CPF and Hirst BH (1993) Ion transport by human endometrial epithelia in vitro. Human Reproduction 8 1570-1575

O'Grady SM, Palfrey HC and Field M (1987) Characteristics and functions of $\mathrm{Na}-\mathrm{K}-\mathrm{Cl}$ cotransport in epithelial tissues American Journal of Physiology 253 C177-C192

Quinton PM (1990) Cystic fibrosis: a disease in electrolyte transport The FASEB Journal 4 2709-2717

Yamaya M, Sekizawa K, Kakuta Y, Ohrui T, Sawai T and Sasaki H (1996) $\mathrm{P}_{2 \mathrm{u}}$-purinoceptor regulation of chloride secretion in cultured human tracheal submucosal glands American Journal of Physiology 270 L979-L984 